\title{
Obraz wojny domowej z lat 83-82 p.n.e. w Żyocie Lucjusza Korneliusza Sulli Plutarcha z Cheronei
}

\section{Tomasz ŁADON**}

\begin{abstract}
An image of the civil war of the years 83-82 BCE in Plutarch's the Life of Sulla: The author of this article is interested in how Plutarch of Chaeronea created the picture of the Sullan War in Parallel lives, especially in the Life of Lucius Cornelius Sulla. Firstly, the author notes that in presenting the civil war Plutarch was dependent on the Memoirs of Sulla. But not only. There are fragments from other source too, probably the same that Appian of Alexandria used. Therefore the Author wonders to what extend Plutarch was tendentious in presenting the Sullan War. Secondly, the author shows which moments of the Sullan War were of especial interest to Plutarch of Chaeronea and tries to answer why some of the events (for example the negotiations between Sulla and Scipio) Plutarch was to described so briefly. Finally, the author indicates why this report of Plutarch of Chaeronea remains a very important source for any historian of the civil wars in Rome.
\end{abstract}

\section{KEYWORDS}

Plutarch; Lucius Cornelius Sulla; First Civil War; Late Roman Republic; Sulla's Commentarii

* Dr, adiunkt w Instytucie Historii, Akademia im. Jana Długosza w Częstochowie. E-mail: tladon@wp.pl. 
Wiosną 83 roku $^{1}$ Lucjusz Korneliusz Sulla, powracający z wojny z Mitrydatesem VI Eupatorem, wylądował wraz z wojskiem na wybrzeżu Italii. Przybył, aby odebrać władzę popularom, którzy po jego wyjeździe na Wschód siłą przejęli rządy w Republice. Na spotkanie mu wyruszyli na czele ogromnej, dwudziestolegionowej armii ówcześni konsulowie: Gajusz Norbanus i Lucjusz Korneliusz Scypion, polityczni spadkobiercy Gajusza Mariusza i Lucjusza Korneliusza Cynny. W ten sposób rozpoczął się ostatni etap pierwszej wojny domowej, zwany — zwłaszcza w dawniejszej historiografii — „wojną sullańską” (Linden, 1896; Pozzi, 1913/1914: 641-679; Piotrowicz, 1921: 118-125).

Wojna domowa $\mathrm{z}$ lat 83-82 znalazła swoje odbicie w wielu relacjach antycznych ${ }^{2}$, była także przedmiotem zainteresowania autorów współczesnych (Pozzi, 1913/1914: 641-679; Lanzani, 1915: 255-371; Hinard, 1985: 165-189; Keaveney, 1982: 129-147; Cambridge Ancient History (CAH), 1994, IX: 187-197 (Seager); Letzner, 2000: 218-245; Christ, 2002: 103-113; Brizzi, 2004: 141-155; Fündling, 2010: 101-111). W niniejszym artykule interesować mnie będzie sposób, w jaki konflikt ów został przedstawiony w Żywotach równoległych Plutarcha z Cheronei. Podstawą rozważań będzie żywot Lucjusza Korneliusza Sulli, choć odwoływać będę się również do biografii Marka Licyniusza Krassusa i Kwintusa Sertoriusza, także zaangażowanych w zmagania wojenne w latach 83-82 (Plutarch Sertorius 6, 2; Crassus 6, 2-6) ${ }^{3}$. Rzadziej będę za to sięgał do biografii Pompejusza, bo choć Plutarch dość szeroko opisał w niej wojnę domową (Pompeius 6,1-8, 6), to skupił się jednak wyłącznie na działalności tego wodza. Ponieważ zaś Sulla i Pompejusz prowadzili działania osobno, żywot Pompejusza tylko w minimalnym stopniu przydatny był w prowadzonych tu badaniach.

Spojrzenie na wojnę przez pryzmat twórczości Plutarcha to zadanie niełatwe ${ }^{4}$. Autor Żywotów równoległych nie był historykiem ${ }^{5}$, nie interesowały go ani wielka polityka, ani konflikty zbrojne. Nie dbał także o chronologię wypadków czy o drobiazgowe ich przedstawianie. W centrum jego uwagi znajdował się charakter człowieka, którego biografię kreślił. Zastanawiał się zatem, czy jego bohater dokonał w życiu dobrych czy złych wyborów, czy sprzyjało mu szczęście

${ }^{1}$ Daty w tekście artykułu dotyczą czasów przed naszą erą.

${ }^{2}$ Informacje źródłowe na temat tego zagadnienia zebrał Broughton, 1952: 62-72.

${ }^{3} \mathrm{O}$ późnorepublikańskich żywotach Plutarcha zob. Hillard, 1987: 19-48.

${ }^{4} \mathrm{Na}$ temat Plutarcha z Cheronei i jego pism zob. Ziegler, 1951: 636-962; Barrow, 1967; Jones, 1971; Korus, 2004: 21-53.

${ }^{5}$ W sławnym wstępie do Żywotu Aleksandra Wielkiego dał wyraźną wykładnię swojego postępowania w pracy przy żywotach: „nie piszę przecież historii, lecz tylko biografie”. Uważat, że „nieraz jakiś prosty czyn, jakieś krótkie powiedzenie czy nawet żart lepiej naświetlają wrodzone cechy ludzkiej natury niż bitwy, w których padły tysiące zabitych, niż ustawianie do walki olbrzymich wojsk czy też obleganie potężnych miast”, Plutarch Alexander 1. Zob. także Sinko, 1959: 442 n.; Korus, 2004: 37 n. O ile nie zaznaczono inaczej, wszystkie cytaty z dzieł Plutarcha podaję w przekładzie Mieczysława Brożka. 
czy przeciwnie - prześladował pech. Biograf stawiał też pytanie, czego przyszłe pokolenia mogą się na przykładzie opisywanej postaci nauczyć (Konrad, 1994: XXVI i przyp. 9).

Plutarch w obraz opisywanych wydarzeń, w tym i relacji o wojnie sullańskiej, wnosi zatem specyficzny typ narracji historycznej. Rzecz jasna jego celem nie było przedstawienie sullańskiej wojny domowej, stanowiła ona bowiem jedynie fragment w życiorysach bohaterów pisanych przez niego biografii. Eksponuje zatem ich negatywne lub pozytywne zachowania, mniej za to zwraca uwagę na przebieg wypadków czy kwestie chronologiczne. Siłą rzeczy przedstawia więc zniekształcony obraz rzeczywistych zdarzeń. Nie umniejsza to jednak wagi podawanych przez niego informacji - przeciwnie: ich mnogość i zróżnicowanie powodują, że biografie sławnych mężów są w badaniach nad wojną sullańską źródłem podstawowym.

Plutarch nie wypowiada się na temat przyczyn wojny domowej, nie wspomina o motywach ataku Sulli na Italię ani o jego planach. Opis konfliktu rozpoczyna po prostu od informacji o lądowaniu sullańczyków koło Tarentu $(\text { Sulla } 27,4)^{6}$. Jako że Sulla dużą rolę przywiązywał do wszelkich wróżb (Jaczynowska, 1990: 101), od razu po wyjściu na ląd złożył ofiarę, a na wątrobie zwierzęcia ofiarnego ukazał mu się wieniec z dwiema zwisającymi wstęgami triumfalnymi, co zostało zinterpretowane jako jasna zapowiedź jego przyszłego zwycięstwa. Dodatkowo na niebie objawiły się zjawy dwóch walczących ze sobą hufców, co najwidoczniej także uznane zostało za dobry omen (Sulla 27, 4). Oba epizody Plutarch zaczerpnął — jak się uważa — z Pamiętników Sulli (Linden, 1896: 22; Chodźko-Domaniewska, 1962: 102-103) ${ }^{7}$. Nie ma potrzeby zresztą odmawiać im historyczności i być może należy traktować jako element propagandy (Ramage, 1991: 98-99). U progu wojny znaki wróżące zwycięstwo potrzebne były zarówno zabobonnemu Sulli, jak i jego żołnierzom — podbudowały morale armii i wiarę w szczęście wodza.

Pierwsze starcie zbrojne, o którym Plutarch nadmienia w żywocie Sulli, miato miejsce nieopodal góry Tifata $(\text { Sulla } 27,5)^{8}$. Na drodze prokonsula stanęły oddziały cynnańczyków, dowodzone przez konsula Gajusza Norbanusa. Przyszły dyktator natychmiast zdecydował się na poprowadzenie armii do bitwy. Biograf z Cheronei wskazuje, że to legioniści sullańscy wykazywali „powszechny zapał” i „wzmożoną odwagę” (Sulla 27, 5), niemniej Sulla najwyraźniej obawiał się

${ }^{6}$ Appian (Bella civilia $[B C]$ I 79, 363) podaje, że Sulla wylądował w Brundyzjum. Niewykluczone, że okręty płynęły w dwóch grupach, część wylądowała w Brundyzjum, część w Tarencie (Keaveney, 1982: 129).

${ }^{7}$ Commentarii Sulli były jednym z głównych źródeł Plutarcha w opisie wojny sullańskiej. Biograf kilkakrotnie się na nie powołuje. Zob. Plutarch Sulla 27, 3; 27, 6; 28, 8 a także Peter, 1865: 67. O dziele Sulli: Kumaniecki, 1977: 116-117; Tatum, 2011: 163-174.

${ }^{8}$ Por. Sulla Fr. 18 (Peter); Livius Periochae LXXXV; Vell. II 25, 4; Appian BC I 84, 382. Szerzej: Pozzi, 1913/1914: 655-657. O lokalizacji góry: Philipp, 1936: 932-933. 
o wierność swoich żołnierzy w przypadku niepowodzenia. Sam przyznawał później w cytowanych przez Plutarcha Pamiętnikach, że „tylko na skutek zwycięstwa jego żołnierze nie rozproszyli się po miastach i gminach, lecz nadal trwali przy nim, nie bojąc się odtąd przeciwnika mimo jego przewagi liczebnej” (Sulla 27, 6 = Sulla, Fr. 18 Peter). Wydaje się zatem, że podbudowanie morale armii u progu kampanii było dla Sulli kwestią bardzo istotną i palącą.

Zwycięstwo przyszłego dyktatora było całkowite. Pod górą Tifata Norbanus stracił 7 tys. żołnierzy (Sulla 27, 5) ${ }^{9}$ i po klęsce wycofał się do Kapui. Po tym sukcesie prokonsul skierował swe sity przeciwko drugiemu konsulowi, L. Korneliuszowi Scypionowi. Wiedząc jednak, że dysponuje on silną armią, postanowił rozpocząć rokowania. Według Plutarcha prawdziwym powodem podjęcia rozmów nie była jednak chęć zawarcia porozumienia ${ }^{10}$. W rzeczywistości był to podstęp mający na celu zwerbowanie żołnierzy Scypiona do własnej armii (Sulla 28, 2; Sertorius 6, 2) ${ }^{11}$. Plan udał się wyśmienicie - czterdzieści kohort (czyli cztery legiony) dowodzonych dotąd przez konsula przeszło na stronę Sulli. Osamotniony Scypion został wypuszczony przez przyszłego dyktatora na wolność (Sulla 28, 1-3; por. Broughton, 1952: 62; Pozzi, 1913/1914: 657-658; CAH 1994, IX: 189-190 (Seager); Bertinelli Angeli et al., 1997: 381; Barden Dowling, 2000: 321).

W epizodzie ze Scypionem Plutarch przedstawia wyraźnie innego Sullę niż na początku kampanii. Jest to człowiek wyćwiczony w „chytrości i oszustwie”, tacy są też podlegający mu żołnierze (Sulla 28,2$)$. Można podejrzewać, że o ile do tej pory $\mathrm{w}$ opisie wojny sullańskiej Plutarch opierał się przeważnie na $\mathrm{Pa}$ miętnikach Sulli, to opisując epizod z pozyskaniem żołnierzy Scypiona, korzystał z jakiegoś innego, mniej przychylnego przyszłemu dyktatorowi, źródła (Linden, 1896: 22; Piotrowicz, 1921: 122-123).

O rokowaniach Scypiona i Sulli biograf z Cheronei wspomina także w żywocie Sertoriusza. Jest to zaledwie drobna, dwuzdaniowa wzmianka, w której Plutarch informuje, że inicjatorem negocjacji był Sulla. Wódz miał jednak od początku nieuczciwe intencje i pod pozorem możliwości zachowania pokoju potajemnie przekupywał legionistów Scypiona, zapewne po to, by porzucili swego wodza i przeszli na jego stronę. Sertoriusz, który towarzyszył konsulowi, bezskutecznie ostrzegał go przed niecnymi zamiarami Sulli. Zniechęcony odjechał wreszcie do Hiszpanii (Plutarch Sertorius 6, 2). Wydźwięk informacji w obydwu żywotach jest podobny, można więc domniemywać, że Plutarch zaczerpnął je z tego samego źródła.

${ }^{9}$ O 7 tys. zabitych wspomina też Orozjusz (V 20, 2). Appian (BC I 84, 382) i Eutropiusz (V 7) twierdzą, że poległo 6 tys. żołnierzy Norbanusa. Appian dodaje, że po stronie Sulli zginęło 70 żołnierzy i tak duża dysproporcja każe podejrzewać, że dane swe pośrednio czerpał z Pamiętników Sulli. Zob. Piotrowicz, 1921: 121, przyp. 3. O wątpliwościach co do liczb podawanych w Pamiętnikach Salmon, 1964: 72.

${ }^{10}$ Por. dyskusja na temat motywów Sulli w Keaveney, 1982: 132-135.

${ }^{11}$ Por. Livius Periochae LXXXV; Vell II 25, 4; Plutarch Pompeius 7, 3; Appian BC I, 85. 
Interesujące, że negocjacje Scypiona i Sulli obszerniej opisane zostały przez innych autorów źródeł (Broughton, 1952: 62). Przede wszystkim wiadomo, że w rozmowach znacznie większą rolę, niż opisał to Plutarch, odegrał Sertoriusz. Prawdopodobnie był on nawet bezpośrednio zaangażowany w prowadzone pertraktacje (Cicero Phil. 12, 27; por. Spann, 1987: 35-36), a po zawarciu rozejmu osobiście miał wyjechać do Kapui, aby poinformować konsula Norbanusa o wyniku rozmów (Appian BC I 85, 384). Sertoriusz zboczył jednak z drogi i zajął sprzyjające Sulli miasto Suessa. Według Appiana, a także niektórych współczesnych historyków, ten postępek czyni go odpowiedzialnym za zerwanie porozumienia, które miało szansę zapobiec dalszej wojnie (Appian $B C$ I 85, 385-386; Frier, 1971: 600-601; Keaveney, 1982: 133-134). Oczywiście szczegóły zajęcia Suessy i rola Sertoriusza w omawianych wydarzeniach były już przedmiotem badań, a spory i polemiki na ten temat toczą się do dzisiaj ${ }^{12}$. Dla niniejszych rozważań ciekawa jest kwestia pominięcia przez Plutarcha tego znaczącego wszak epizodu w Żywotach równolegtych.

Brak wzmianki o zdobyciu Suessy w biografii Sertoriusza to prawdopodobnie celowy zabieg biografa z Cheronei, który nie chciał obciążać bohatera żywotu udziałem w tym co najmniej dwuznacznym wydarzeniu. Oskarżenie o zerwanie zawieszenia broni w sytuacji, w której Plutarch starał się podkreślać umiar i rozsądek Sertoriusza na tle nieudolności innych przywódców popularów, zburzyłoby konstrukcję żywotu. W dodatku niefortunne zdarzenie miało miejsce bezpośrednio przed wyjazdem Sertoriusza do Hiszpanii, co miało otworzyć nowy, znaczący etap życia tego bohatera. Plutarch wolał więc sprawę Suessy przemilczeć (Ładoń, 2011: 37-38). Możliwe także, że akurat w tym fragmencie biografii podążał za Salustiuszem, który był jednym z jego głównych źródeł w pisaniu żywotu Sertoriusza (Piotrowicz, 1921: 164-165; zob. też Radnitzky, 1908/1909: 3-19; Scardigli, 1971: 33-64; Garcia Moreno, 1992: 132-158; Appel, 2004: 193-195). Wskazuje na to krótki fragment Historii identyfikowany z omawianym wydarzeniem oraz wzmianka Eksuperancjusza, który dzieło historyka z Amiternum kilka wieków później streścił'13.

Trudniej wytłumaczyć brak opisu zdobycia Suessy przez Sertoriusza w żywocie Sulli. Jeśli postępek posłańca Scypiona rzeczywiście doprowadził do zerwania rokowań pokojowych, to stanowiło to doskonały pretekst do zrzucenia odpowiedzialności za wznowienie wojny domowej na cynnańczyków. Plutarch musiał wiedzieć o incydencie, wspominat o nim niemal na pewno w swych Pamiętnikach Sulla. Najwidoczniej, jak już nadmieniałem, biograf, kreśląc negocjacje ze Scypionem, korzystał jednak akurat z jakiegoś innego źródła. Wszak to żołnierzy Sulli oskarża o podstępne namówienie legionistów Scypiona, by

\footnotetext{
${ }^{12}$ Ostatnio dyskusję podsumował Juan Strisino (Strisino, 2002: 33-40).

${ }^{13}$ Sall. Hist. I,91[Maurenbrecher]=I,81[McGushin]: „Cuius advorsa voluntate colloquio militibus permisso, corruptio facta paucorum, et exercitus Sullae datus est”. Por. Exuper. 7, 13-15; Konrad, 1994: 82.
} 
porzucili wodza i przeszli na stronę ich dowódcy, i trudno sobie wyobrazić, aby taka wersja zdarzeń pochodziła z dziełka przyszłego dyktatora. Tradycja Pamiętników przetrwała za to wyraźnie w przekazie Appiana, który zdradę legionistów Scypiona przedstawia jako ich własną inicjatywę i nie wspomina nic o żadnych niecnych namowach sullańczyków (Appian $B C$ I 86, 383; 86, 386; Gabba, 1958: 223-224; Konrad, 1994: 81-82).

Po zrelacjonowaniu negocjacji Sulli ze Scypionem Plutarch pomija przebieg dalszych działań wojennych w 83 roku i od razu przechodzi do relacjonowania wydarzeń roku 82. Przeciwnikiem Sulli tym razem był Mariusz Młodszy, konsul tego roku, który dzięki sławie ojca w wieku zaledwie 26 lub 27 lat objął najwyższy urząd w państwie. Do bitwy między Sullą a Mariuszem doszło nieda-

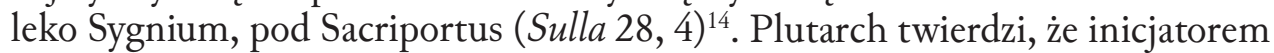
starcia był młody konsul, dysponujący wyraźną przewagą liczebną ${ }^{15}$. Próbował on zaskoczyć Sullę w momencie, gdy jego żołnierze rozstawiali obóz. Zaskoczeniu sprzyjać miały ulewne opady deszczu. Atak się nie udał — żołnierze przyszłego dyktatora stawili dzielny opór, a następnie przeszli do kontrofensywy i zmusili Mariusza do ucieczki. Pokonany konsul w ostatniej chwili znalazł schronienie w Praeneste (Sulla 8, 4) ${ }^{16}$.

Plutarch w opisie bitwy znów wyraźnie podąża za Pamiętnikami Sulli. Świadczy o tym odwołanie się do widzenia sennego, jakie nawiedzić miało przyszłego dyktatora w noc poprzedzającą starcie. Śnił mu się ponoć stary Mariusz, który napominał swego syna, aby strzegł się nadciągającego dnia (Sulla 28, 4). Bezpośrednio na Sullę, jako swego informatora, wskazuje także Plutarch przy odnotowaniu strat poniesionych $\mathrm{w}$ trakcie bitwy: śmierć miało ponieść 20 tys. mariańczyków, a 8 tys. - dostać się do niewoli. Po stronie Sulli zginąć miało zaś jedynie 23 legionistów (Sulla 28, 8). Plutarch pomija również istotny fakt przejścia na stronę przyszłego dyktatora części wojska Mariusza, co w dużym stopniu wpłynęło na przebieg bitwy (por. Appian BC I 87, 398-399). Zaniedbanie biografa jest zapewne wynikiem braku wspomnianego szczegółu w Pamiętnikach Sulli. Plutarcha to nie usprawiedliwia i stanowi kolejny dowód jego nierzetelności historycznej, ale i potwierdzenie bagatelizowania przez niego tego typu „drobnostek”.

We fragmencie dotyczącym bitwy pod Sacriportus Plutarch dodaje opowieść o tym, jakoby Mariusz nie uczestniczył w pierwszym etapie starcia, gdyż spał wówczas zmęczony i zdołano go rozbudzić dopiero, gdy żołnierze rozpoczęli już odwrót. Jak to często bywa w przypadku nieufności biografa do autora przekazu, powołuje się na niego imiennie (Korus, 2004: 39). Informatorem

${ }^{14}$ O lokalizacji zob. Pozzi, 1913/1914: 667; Philipp, 1920: 1681; Gabba, 1967: 230.

${ }^{15}$ Biograf podaje, że Mariusz Młodszy dysponował 85 kohortami żołnierzy. Z wcześniejszych wzmianek Plutarcha można wnioskować, że u boku Sulli zebranych było 60 kohort.

${ }^{16}$ Zob. Broughton, 1952: 66 o pozostałych źródłach; także Pozzi, 1913/1914: 667; Keaveney, 1982: 137-138; Letzner, 2000: 237-238; Christ, 2002: 108; Fündling, 2010: 105-106. 
Plutarcha o tym zdarzeniu był Fenestella, choć biograf dodaje, że nie był on jedynym historykiem, który opowieść tę przekazał (Sulla 28, 7) ${ }^{17}$.

Po opisie bitwy pod Sacriportus Plutarch radykalnie skraca opowieść o następnych wypadkach. Wspomina jedynie, że podobne szczęście jak Sulla mieli inni jego wodzowie: Pompejusz, Krassus, Metellus i Serwiliusz, co w konsekwencji doprowadziło drugiego z konsulów, Karbona, do ucieczki do Afryki. Nie pisze zatem Plutarch ani o pościgu Sulli za Mariuszem i oblężeniu Praeneste, ani o bitwie $z$ Karbonem pod Kluzjum ${ }^{18}$.

Do relacji z działań wojennych biograf powraca dopiero przy opisie bitwy koło Bramy Kollińskiej. Jest to dla niego kulminacyjny punkt w opisie wojny sullańskiej. Przeciwnikami Sulli, a pisze o nich Plutarch z wyraźnym uznaniem, byli wódz Samnitów Telesynos i wódz Lukanów Lamponiusz (Sulla 29, 1) ${ }^{19}$. Początkowo planowali oni uwolnić oblegane przez Sullę Praeneste. Przyszły dyktator nie dał się jednak wciągnąć w bitwę na warunkach Italików, wobec czego Telesynos użył podstępu i poprowadził pozorowany atak na Rzym. Po podjechaniu pod Bramę Kollińską wódz Samnitów zatrzymał armię i rozkazał rozbić obóz. Plutarch nie wyjaśnia, dlaczego nie zaatakował miasta. Prawdopodobnie Telesynos spodziewał się, że pod Rzym szybko przybędzie Sulla, i chciał być na to przygotowany. Priorytetem było pokonanie armii sullańskiej, ewentualne plądrowanie miasta można było odłożyć na później.

Plutarch odnotowuje wyraźne zaniepokojenie mieszkańców Rzymu pojawieniem się armii Italików. Część arystokratycznej młodzieży dokonała nawet nieudanego wypadu za mury, podczas którego śmierć poniósł bliżej nieznany Appiusz Klaudiusz. Spotęgowało to tylko zamieszanie w stolicy.

Sulla najwidoczniej obawiał się, że Telesynos zainicjuje atak na Rzym, wysłał bowiem przodem siedmiuset jeźdźców dowodzonych przez Oktawiusza Balbusa. Kiedy tylko przybyli oni pod miasto, niemal natychmiast zaatakowali wroga. Skąd ten pośpiech i jaki był wynik starcia - o tym Plutarch nie pisze. To, że Balbus nie poczekał na Sullę i uderzył od razu, każe się domyślać, że coś go sprowokowało do natychmiastowego działania. Być może ruszył na pomoc niedobitkom młodych nobilów, którzy przed bramą potykali się jeszcze z Italikami.

Sulla pod Rzym nadciągnął niedługo po Balbusie, o czym świadczy informacja, że zaraz po przybyciu jego żołnierze zjedli śniadanie. Mimo nacisków oficerów Dolabelli i Torkwatusa, argumentujących, że wojsko jest zmęczone nocnym marszem, Sulla rozkazał ustawić się żołnierzom w szyku bojowym. Motywów pośpiechu przyszłego dyktatora biograf nie tłumaczy. Bitwa rozpoczęła

${ }^{17}$ O Fenestelli zob. Wissowa, 1909: 2177-2179; Cornell, 2013: 489-496.

${ }^{18} \mathrm{O}$ przebiegu wojny między bitwą pod Sacriportus a bitwą koło Bramy Kollińskiej zob. np. Keaveney, 1982: 138-142.

${ }^{19}$ O udziale Samnitów i Lukanów w wojnie sullańskiej zob. Salmon, 1964: 70-79, szczeg. 74-79. 
się o dziesiątej godzinie dnia ${ }^{20}$, czyli według współczesnej rachuby o 4 po południu, około godziny przed zachodem słońca.

Opis bitwy u Bramy Kollińskiej w żywocie Sulli jest mało dokładny. Plutarch podaje, że prawym skrzydłem sullańczyków dowodził Krassus i wiadomo, że szybko udało mu się przełamać opór przeciwnika (Sulla 29, 5; Crassus 6, 6; Piegdoń, 2011: 41; Ładoń 2015: 161). O dowódcy lewego skrzydła biograf nie wspomina, ale jako że sytuacja szybko stała się tam groźna, Sulla pogalopował osobiście na charakterystycznym białym koniu, licząc zapewne na to, że jego obecność wzmoże ducha walki u żołnierzy. W drodze został rozpoznany przez żołnierzy italskich i tylko cudem uniknął ciśniętych w niego śmiercionośnych oszczepów. Wspominał później w swych Pamiętnikach (Sulla 29, 6) ${ }^{21}$, że ocalenie zawdzięczał figurce Apollina Pytyjskiego, którą miał zwyczaj stale nosić przy sobie w trakcie bitew ${ }^{22}$.

Według Plutarcha osobista interwencja Sulli na lewym skrzydle na niewiele się zdała. Wróg zwyciężył, a przyszły dyktator zmuszony był wraz z innymi szukać schronienia w obozie. Pod Praeneste, gdzie oblężenia pilnował Lukrecjusz Ofella, dotarły nawet plotki o śmierci przyszłego dyktatora i zajęciu Rzymu przez Italików. Relacja o bitwie gwałtownie się urywa i dalej biograf opisuje, jak do Sulli przybyli po prowiant żołnierze Krassusa, którzy poinformowali go o wielkich stratach wroga, decydującym zwycięstwie na prawym skrzydle oraz oblężeniu Italików w pobliskiej Antemnie (Sulla 30, 1; por. Crassus 6, 6). Sulla udał się tam skoro świt. Po jego przybyciu 3 tys. żołnierzy wroga przeszło na jego stronę i poprosiło o łaskę. Dla potwierdzenia ich lojalności rozkazał im wówczas zaatakować pobratymców. Ocaleli — zarówno ci, którzy się do niego przyłączyli, jak i ci którzy poddali mu się już w trakcie bratobójczej potyczki w liczbie 6 tys. zostali zebrani w jednym miejscu i na rozkaz Sulli zgładzeni. Wojna była skończona, rozpoczął się czas odwetu.

W Plutarchowym opisie bitwy u Bramy Kollińskiej można zauważyć wyraźną lukę. Opis ten de facto kończy się wszak ukazaniem klęski Sulli. Plutarch nie informuje także, co stało się ze zwycięskim prawym skrzydłem Italików, które pobiło wojska przyszłego dyktatora ${ }^{23}$. Od szczegółów militarnych dla biografa ważniejsze było wyeksponowanie wydarzeń dnia następnego. Pokazanie bezwzględności i brutalności zwycięzcy jest dla Plutarcha doskonałym

${ }^{20}$ Daty dziennej Plutarch nie podaje. Dzięki Wellejuszowi Paterkulusowi (II 27, 1) wiadomo, że starcie miało miejsce 1 listopada 82 roku.

${ }^{21}$ Plutarch co prawda w tym miejscu nie powołuje się literalnie na Pamiętniki Sulli, ale charakterystyczne odniesienie do przychylności bogów każe podejrzewać, że w tym fragmencie znów podążał za dziełkiem przyszłego dyktatora. Zob. Brenk, 1977: 242.

22 Figurka ta najpewniej została zrabowana przez Sullę ze świątyni w Delfach w 86 roku. Por. Plutarch Sulla 12; Jaczynowska, 1990: 102.

${ }^{23}$ Częściowo te kwestie rozjaśniają autorzy innych źródeł, choć wciąż pozostają wątpliwości. O dyskusji na temat bitwy pod Bramą Kollińską zob. Keaveney, 1982: 146-147, przyp. 28; Ładoń, 2015: 155-167. Źródła zebrał Broughton, 1952: 69. 
wstępem do opisu kolejnych represji, które Sulla prowadził już po objęciu dyktatury (Sulla 31-32).

Obraz ostatniego etapu pierwszej wojny domowej, jaki wyłania się z żywotu Lucjusza Korneliusza Sulli, jest niełatwy do oceny. Plutarch skupia się oczywiście przede wszystkim na bohaterze żywotu, wobec czego istnieje bezpośrednia zależność między prezentacją wojny i Sulli. Ponieważ zaś większość wiadomości w relacjonowaniu konfliktu biograf czerpał z Pamiętników dyktatora, przemycił w związku z tym jednocześnie propagandę w nich zawartą. Sulla jawi się zatem w żywocie często jako wybranek Fortuny i ulubieniec bogów. Ugruntowało to we współczesnej historiografii opinię, że Plutarch wykreował pozytywny wizerunek Sulli (Scardigli, 1979: 89). Opinia ta nie zawsze jest miarodajna. Kiedy bowiem biograf z Cheronei sięgał do innych źródeł niż sullańskie Commentarii, ukazywał czasem — jak to określił Philip A. Stadter — „Sulla's dark side” (Stadter, 1992: 43). Dokładnie ten schemat można odnieść do wizerunku Sulli z relacji o wojnie domowej. Tam gdzie Plutarch podąża za Pamiętnikami dyktatora, wizerunek ten jest pozytywny, zwycięstwa wodza błyskotliwe, w bitwach przez niego prowadzonych giną tysiące wrogów, jego zaś straty są minimalne. Kiedy jednak biograf czerpie z jakiegoś innego źródła, zapewne tego samego, z którego korzystał Appian w I księdze Wojen domowych, przedstawienie Sulli w żywocie nie jest już tak jednostronne, co bezpośrednio wpływa także na prezentowany tam obraz wojny domowej.

Mimo przemycenia do żywotu propagandy sullańskiej Plutarch zachowuje wiarygodność, jeśli chodzi o podawane informacje. Nie przeinacza ich, nie pomija także ważnych wydarzeń. Nie zmienia to faktu, że w porównaniu z Appianem - oczywiście w odniesieniu do omawianego tutaj konfliktu — zdaje się jednak mniej obiektywny. Wynika to prawdopodobnie z tego, że historyk z Aleksandrii w opisie pierwszej wojny domowej w mniejszym stopniu korzystał z Pamiętników dyktatora, a więcej czerpał ze źródła, które przyszłemu dyktatorowi było znacznie mniej przychylne (Piotrowicz, 1921: 118-134; Chodźko-Domaniewska, 1962: 75-76).

Plutarch w opisie wojny domowej w żywocie Sulli przeważnie zachowuje porządek chronologiczny. Łamie go tylko wtedy, gdy wtrąca jakiś przykład, mający wyeksponować sytuację, w jakiej znalazł się Sulla ${ }^{24}$. Świadomie wybiera fakty najważniejsze, koncentruje się na tych, w których uczestniczy przyszły dyktator, a jeśli czyni do innych wydarzeń dygresje, to są one krótkie i pobieżne (por. Sulla 28, 8).

${ }^{24}$ Przykładem może być wspomniana w początkowej fazie relacji o wojnie bitwa pod Fidencją, która w rzeczywistości stoczona była znacznie później (Plutarch Sulla 27, 7-8; por. Broughton, 1952: 70). Dla Plutarcha bitwa miała być tylko przykładem potwierdzającym fakt dysproporcji w liczebności armii, z jakimi musiał się borykać zarówno Sulla, jak i jego wodzowie. Sama bitwa biografa nie interesowała i nie wrócił on już do niej $\mathrm{w}$ dalszej części żywotu. Por. Piotrowicz, 1921: 122. 
Utrudnieniem dla historyka próbującego zrekonstruować wojnę sullańską przy pomocy żywotu Sulli jest fakt, że militarne zmagania zajmowały Plutarcha tylko w ograniczonym stopniu. Wymienia on co prawda najważniejsze bitwy kampanii, ale stroni od ich opisów. Jeśli jakieś starcie relacjonuje bardziej szczegółowo, często robi to nieporadnie. Przy podawaniu strat poniesionych $\mathrm{w}$ trakcie bitew bezkrytycznie powtarza dane zaczerpnięte od Sulli. Relacją z wojny domowej Plutarch daje zatem jeszcze raz dowód, że wojna była dla niego jedynie tłem w przedstawianiu charakteru bohatera żywotu. Mimo wszelkich niedoskonałości Plutarchowy żywot Sulli to jedno z podstawowych źródeł do poznania dziejów ostatniego etapu pierwszej wojny domowej.

\section{ZASADY PRZYWOŁYWANIA TEKSTÓW ŹRÓDŁOWYCH}

Odwołania do tekstów Plutarcha wedle podziału stosowanego w krytycznych wydaniach $\dot{Z} y$ wotów równolegtych (tytuł biografii, rozdział, paragraf). Wszystkie teksty greckie (a także odniesienia) wedle bazy danych Thesaurus Linguae Graecae ${ }^{\circledR}$ Digital Library. (Ed. M. C. Pantelia). Irvine: University of California. [Online:] http://www.tlg.uci.edu (dostęp: 28.12.2017). Odwołania do tekstów autorów rzymskich również wedle podziałów przyjętych w edycjach krytycznych stosownych autorów (księga, rozdział, [paragraf]):

Appian z Aleksandrii: Appianus, Bella civilia. Ed. L. Mendelssohn \& P. Viereck. Leipzig: K.G. Saur Verlag Gmbh \& Co 1986 (reprint z 1905).

Livius: Tite-Live. Histoire romaine. T. 34, Abrégés des livres de l'Histoire romaine de Tite-Live. Ptie. 1, 'Periochae' transmises par les manuscrits (Periochae 1-69). Texte établi et traduit par P. Jal. Paris: Les Belles Lettres 1984.

Orozjusz Historiarum Adversum Paganos Libri VII: Orosius Histoire (contre les païens). Texte établi et traduit par M.-P. Arnaud-Lindet. Paris: Les Belles Lettres 1991.

Sallustius The Histories: Vol. 1: Books 1-2 (Clarendon Ancient History Series). Trans. and commentary by P. McGushin. Cambridge: Cambridge University Press 1992.

Velleius Paterculus: C. Vellei Paterculi ex Historiae Romanae libris duobus quae supersunt. Lipsiae: In aedibus B. G. Teubneri 1933.

\section{BIBLIOGRAFIA}

Appel, H. (2004). Animus liber. Kwestia obiektywizmu w pisarstwie bistorycznym Sallustiusza. Toruń: Dom Organizatora.

Barden Dowling, M. (2000). The Clemency of Sulla. Historia, 49, 303-340.

Barrow, R. H. (1967). Plutarch and bis times. Bloomington: Indiana University Press.

Bertinelli Angeli, M. G. et. al. (1997). Plutarco, Le vite di Lisandro e di Silla. Rome: Mondadori. Brenk, F. E. (1977). In mist appareled: Religious themes in Plutarch's Moralia and Lives. Leiden: E. J. Brill.

Brizzi, G. (2004). Silla. Roma: Mondadori.

Broughton, T. R. S. (1952). The magistrates of the Roman Republic (t. 2). New York: American Philological Association. 
Cornell, T. J. (Red.). (2013). The fragments of the Roman bistorians (t. 1). Oxford: Oxford University Press.

Crook, J. A., Lintott, A., \& Rawson, E. (Red.). (1994). Cambridge ancient bistory (t. 9). Cambridge: Cambridge University Press.

Chodźko-Domaniewska, A. (1962). Tendencje historiografii rzymskiej na przełomie II i I wieku. Roczniki Humanistyczne KUL, 11, 63-138.

Christ, K. (2002). Sulla. Eine römische Karierre. München: C.H. Beck.

Frier, B. W. (1971). Sulla's propaganda: The collapse of the Cinnan republic. American Journal of Philology, 92, 585-604.

Fünding J. (2010). Sulla. Darmstadt: Wissenschaftliche Buchgesellschaft.

Gabba, E. (Wstęp i oprac.). (1958). Appiani Bellorum civilium liber primus. Firenze: La „Nuova Italia” Editrice.

Garcia Moreno, L. A. (1992). Paradoxography and political ideals in Plutarch's Life of Sertorius (s. 132-158). W: P. A. Stadter (Red.). Plutarch and the historical tradition. London-New York: Routlege.

Hillard, T. W. (1987). Plutarch's Late-Republican Lives: Between the lines. Anticbton, 21, 19-48.

Hinard, F. (1985). Sylla. Paris: Fayard.

Jaczynowska, M. (1990). Religie świata rzymskiego. Warszawa: Wydawnictwo Naukowe PWN.

Jones, C. P. (1971). Plutarch and Rome. Oxford: Oxford University Press.

Keaveney, A. (1982). Sulla: The last Republican. London-Canberra: Routlege.

Konrad, Ch. F. (1994). Plutarch's Sertorius: A Historical commentary. Chapel Hill-London: University of North Carolina Press.

Korus, K. (2004). Arystokrata ducha (t. 1; s. 21-53). W: Plutarch z Cheronei, Żywoty równoległe. Warszawa: Biblioteka Antyczna.

Kumaniecki, K. (1977). Literatura rzymska. Okres cyceronski. Warszawa: Wydawnictwo Naukowe PWN.

Lanzani, C. (1915). Mario e Silla. Storia della democrazia romana negli anni 87-82 a.Cr. Catania: F. Battiato.

Letzner, W. (2000). Lucius Cornelius Sulla. Versuch einer Biographie. Münster: LIT.

Linden, E. (1896). De bello civili Sullano. Freiburg: Ex Officina C.A. Wagneri.

Ładoń, T. (2011). Wojna sertoriańska (80-71 przed Chr.). Oświęcim: Napoleon V.

Ładoń, T. (2015). Kontrowersje wokół bitwy przy Bramie Kollińskiej (1 listopada 82 r. p.n.e.) (s. 155-167). W: H. Kowalski \& P. Madejski (Red.). Armia, systemy obronne i ideologiczno-religijne aspekty wojny $w$ imperium rzymskim. Lublin: Wydawnictwo UMCS.

Peter, H. (1865). Die Quellen Plutarcbs in den Biograpbieen der Römer. Halle: Verlag der Buchhandlung des Waisenhauses.

Philipp, H. (1920). Sacriportus (t. 2[2], s. 1681). W: Paulys Realencyclopädie der classischen Altertumswissenschaft, Stuttgart: J.B. Metzlersche Verlagsbuchhandlung.

Philipp, H. (1936). Tifata (t. 2[11], s. 932-933). W: Paulys Realencyclopädie der classischen Altertumswissenschaft. Stuttgart: J.B. Metzlersche Verlagsbuchhandlung.

Piegdoń, M. (2011). Krassus. Polityk niespetnionych ambicji. Kraków. Towarzystwo Wydawnicze "Historia Iagellonica”.

Piotrowicz, L. (1921). Plutarch a Appjan. Studja źródłowe do bistorji Rzymu w epoce rewolucji. Okres I (133-70). Poznań: Druk. Zjednoczenia Młodzieży: skł. gł. Gebethner i Wolff.

Pozzi, E. (1913/1914). Studi sulla guerra civile Sillana. Atti della Accademia delle Scienze di Torino, 49, 641-679.

Radnitzky, H. (1908/1909). Plutarchs Quellen in der vita des Sertorius. Jabres-Bericht über das Kaiserlich-Königliche Akademische Gymnasium in Wien, 3-19. 
Ramage, E. S. (1991). Sulla's Propaganda. Klio, 73, 93-121.

Salmon, E. T. (1964). Sulla Redux. Athenaeum, 42, 60-79.

Scardigli, B. (1971). Considerazioni sulle fonti della biografia Plutarchea di Sertorio. Studi Italiani di Filologia Classica, 43, 33-64.

Scardigli, B. (1979). Die Römerbiographien des Plutarcbs. Munich: C.H. Beck.

Sinko, T. (1959). Zarys bistorii literatury greckiej (t. 2). Warszawa: Wydawnictwo Naukowe PWN.

Spann, P. O. (1987). Quintus Sertorius and the legacy of Sulla. Fayetteville: University of Arkansas Press.

Stadter, P. A. (1992). Paradoxical paradigms: Lysander and Sulla (s. 41-55). W: P. A. Stadter (Red.). Plutarch and the bistorical tradition. London-New York: Routlege.

Strisino, J. (2002). Sulla and Scipio 'not to be trusted'? The reasons why Sertorius captured Suessa Aurunca. Latomus, 61, 33-40.

Tatum, J. (2011). The Late Republic: Autobiographies and memoirs in the age of the Civil Wars (s. 161-187). W: G. Marasco (Red.). Political autobiographies and memoirs in Antiquity. Leiden: Brill.

Wissowa, G. (1909). Fenestella (t. 6, s. 2177-2179). W: Paulys Realencyclopädie der classischen Altertumswissenschaft. Stuttgart: J.B. Metzlersche Verlagsbuchhandlung.

Ziegler, K. (1951). Plutarchos von Chaironeia (t. 2[41], s. 636-962). Paulys Realencyclopädie der classischen Altertumswissenschaft. Stuttgart: J.B. Metzlersche Verlagsbuchhandlung. 